\title{
Anxiety and Smoking Behavior of Teenager in Papua, Indonesia
}

\author{
Agussalim $^{1 *}$, Frans Manangsang ${ }^{2}$ and Gutit Enny Susanti ${ }^{3}$ \\ ${ }^{1}$ Nursing School, Health Polytechnic Ministry of Health, Republic of Indonesia \\ ${ }^{2}$ Nursing School, Health Polytechnic Ministry of Health Jayapura, Republic of Indonesia \\ ${ }^{3}$ Nutritionist School, Health Polytechnic Ministry of Health Jayapura, Republic of Indonesia
}

*Corresponding author: Agussalim, Nursing School, Health Polytechnic Ministry of Health, Republic of Indonesia.

\author{
Received Date: March 04, 2020
}

Published Date: March 13, 2020

\begin{abstract}
Introduction: The National Commission on child protection reported receiving an average of 200 case reports of children experiencing anxiety on a monthly basis, throughout in 2015 , increasing $98 \%$ from the previous year. The report of the National Commission on child protection also indicates an increase in anxiety disorders in children in Indonesia. Papua is the province with the youngest percentage of the highest smoking in Indonesia, 3.2\% of children aged 5-9 years in Papua are already smoking.

Method: Using a cross-sectional approach, meaning that all research data is taken at the same time, or each research variable data is collected only once time.

Result: Research shows from 27 students who are not anxious and behave very often there are 18 students, from 2 students who are anxious lightly and behave very often there is 1 person, from 1 student who is anxious and behave often smoke. There were 1 people, and from 1 person who was anxious and behaving smoking sometimes there were 1 people. From the data shows that $\mathrm{P}$ value $=0.01(\mathrm{P}<0.05)$, that there is strong connection between the level of anxiety with smoking behavior in young men at Muhammadiyah Jayapura High School.

Suggestion: It is hoped that the teenagers who are active to further increase their knowledge and insights on the impact of smoking by following counseling-health counseling or accessing information in print or electronic media about the dangers of Smoking.
\end{abstract}

Keywords: Anxiety level, Smoking behavior, Teenagers, Papua, Teenager, Danger

\section{Introduction}

Adolescence begins when a child reaches a ripe age. In its development it will be faster in the early days compared to the expiration. This very short adolescence is characterized as an important period, transitional period, change period, troubled age, time seeking identity, age that raises fear, unrealistic time, and adult time limit [1]. Research on anxiety on teenagers has been conducted in some high schools. In North America, research conducted on 100 participants showed that the anxious prevalence of students was 38\% (Shannone, 2015). The same research conducted by (Firth, 2015) in one of the UK schools involving 165 participants showed the anxious prevalence of students was $31.2 \%$. Meanwhile, three studies conducted in Asia showed the results that in Pakistan, with
161 participants, the prevalence of anxious students was $30.84 \%$ (Shah, Hasan, Malik, \& Sreeramareddy, 2016).

In Malaysia, with 396 participants, the student's anxious prevalence is $41.9 \%$ (Sherina, 2015) and in Saudi Arabia against 494 participants, it is known that the student's anxious prevalence is $57 \%$ where $21.5 \%$ is a mild anxious, $15.8 \%$ anxious and $19.6 \%$ were anxious. The research of Abdulghani (2015) demonstrates the anxiety impact especially perceived by first-year learners, and the final level. Anxiety in students can lead to decreased academic performance, decreased learning concentration, and memory decline. (Carolin, 2010). In the year 2016 National Commission on Child Protection, reported receiving an average of 200 reports of 
children's cases experiencing anxiety on a monthly basis, throughout the year 2015, increasing 98\% from the previous year. The report of the National Commission on Child Protection also indicates an increase in anxiety disorders in children in Indonesia. Friday, (20/03/2015), chairman of the child Protection company by Arist Merdeka Sirait revealed that it has been recorded as many as five children under 18 years trying to conduct a suicide experiment due to anxiety. Two of them have died.

Gusniati Research (Desmita, 2015:290) on students at one of the top schools in Jakarta found an anxiety phenomenon experienced by students at school. About $40.74 \%$ of learners feel overwhelmed by having to defend their school rankings, $62.96 \%$ of learners feel anxious to face a semester exam, $82.72 \%$ of learners feel afraid to get bad replay value, $80,25 \%$ are confused Completing too many homework, and $50.62 \%$ of learners feel exhausted following the extra time of study in school. In line with the expression Nugroho (2015) Children of non-regular programs tend to experience academic anxiety because it gets a burden of study that does not fit the needs. In fact, teenagers can talk about their problems and develop problem-solving skills, but because of the emotional up play and the impossibility of teenagers in making important decisions, making youth need help and support Special of adults [2]. Overcoming anxiety will be easier to do with the help of family and friends. The absence of family and friends to share a sense can cause or worsen the anxiety itself. So, they chose to overcome anxiety when there was a problem with smoking, because by smoking they believed it could relieve anxiety on him (Siswanto, 2009).

Continuous smoking can bring bad impact to the health of the body such as decreased nervous system, blood flow and appetite, increased blood pressure, heart rate, stomach acid, reduced sense of taster and smell, feeling dizzy, nausea as well as caused many dangerous diseases (Syair Abdul, 2009). According to WHO data (2014) is mentioning 1 in 10 deaths in adults is due to smoking, this cigarette kills nearly five million people annually [2-5]. If the habit of smoking continues then it is certain 3 that 10 million people will die of cigarettes. In 2014 there were 5.4 million deaths due to smoking or an average of one death every 6 seconds. Smoking is a very dangerous thing towards decreasing health productivity. Smoking can be the cause of almost $90 \%$ lung cancer, $75 \%$ chronic obstructive pulmonary disease (COPD), and $25 \%$ of the causes of heart attack.

Global Youth Tobacco Survey (GYTS) in 2014, Indonesia obtained, 18.3 percent of our students have a habit of smoking, and the details are 33.9 percent males and 2.5 percent of women. The average smoker Data of Indonesian people (15 years old and above) is about 30 percent, which means that with increasing age, the percentage of the smoker continues to increase. That is, if we can suppress the habit of smoking in young people/students, then we can also expect the number of smokers in adults can be controlled better. Indonesia is one of the countries with the largest smoker of smokers in the Duni. According to the World Health Organization
(WHO) data, in 2014 the percentage of male smokers, 67\%, was far greater than that of a female smoker, $2.7 \%$. Among the smokers there were $56.7 \%$ of men and $1.8 \%$ of women smoked every day [5-9].

Papua is the province with the youngest percentage of the highest smoking in Indonesia, 3.2\% of children aged 5-9 years in Papua are already smoking. For teenagers' groups (15-19 years) are smoking daily in Jayapura city as much as $42.9 \%$ smoke cigarettes within 5 minutes. A survey of several schools in Jayapura City, each student began to smoke with a percentage of $40 \%$ as an active smoker consisting of $35 \%$ of the son and $5 \%$ of the daughter $[10,11]$. Agency for Health Research and Development, Wednesday $(29 / 4 / 2015)$. The habit of smoking in students is due to unfamiliarity information, influence of advertising and influence of friends. Obtained by the Indonesian heart foundation's poll is as much as $77 \%$ of smoking students due to the influence of friends (Imam Satria, 2009). Various facts reveal that the more adolescents smoke then the more likely his friends are smokers as well and so vice versa. From that fact there are two possibilities that occur, the first teenagers were affected by his friends or even the teenage friends were influenced by the teenage self that they eventually all became smokers [12]. Among the youth of smokers there are $87 \%$ have one or more companions that smokers as well as non-smokers Youth (Mu'tadin, 2006).

Based on the results of the interview conducted by the researchers on 27 August 2016 against 7-8 male teenagers in high school Muhammadiyah most of them are smoking because of the anxiety experienced in facing problems or pressure, than Choosing to tell a story to her parents, and a little bit of her choosing to tell her peers to get a solution from her problem, some are resigned and choose to play to forget her problem and not to smoke [13-16]. That is because the youth still lack knowledge in resolving the problem, so that the youth feel that he has no more ability. If it gets pressure or problems, they choose to smoke instead of finding a way out of the problem that is in its face.

\section{Statement of the Problem}

Based on above background, researcher formulated this research problem: "Is there a relationship between anxiety with smoking behavior of male teenagers in Muhammadiyah High School Jayapura, Papua.

\section{Research Method}

This research is a non-experimental study, research to know the relationship between variables. Al-Ummah, 2009. This research is to find out the relationship between variable levels of anxiety to the male teenage adolescent behavior at Muhammadiyah Jayapura High School. The sampling techniques in this study used purposive sampling based on a specific consideration made by researchers, based on the characteristics or properties of a previously known population. 


\section{Result}

\section{Univariate analysis}

Descriptive analysis (Univariate Analysis) is intended to describe the frequency distribution of respondents responses. Based on the observation results had to give a general idea of the relationship of anxiety level with the male teenage behavior of young men in Muhammadiyah Jayapura High school 2017.

\section{Respondent characteristic}

Age: The Data in Table 1 shows that there are young men with 16 years of age numbering 11 people (35.5), 17 years old numbering 19 (61.3), 18 years old amounted to 1 person (3.2).

Table 1: Respondents based distribution age.

\begin{tabular}{|c|c|c|}
\hline Age & N & \% \\
\hline 16 years & 11 & 35.5 \\
\hline 17 years & 19 & 61.3 \\
\hline 18 years & 1 & 3.2 \\
\hline Total & 31 & 100 \\
\hline
\end{tabular}

\section{Religion}

Table 2: The distribution of respondents based on the religion.

\begin{tabular}{|c|c|c|}
\hline Religion & $\mathbf{N}$ & $\%$ \\
\hline Islam & 31 & 100 \\
\hline Christian & 0 & 0 \\
\hline Catholic & 0 & 0 \\
\hline Total & 31 & 100 \\
\hline
\end{tabular}

Data in (Table 2) shows that the majority of religions embraced by male adolescents in Jayapura High School are 100\% of Islamic religions.

\section{First time smoking}

Data on Table 3 indicates that there is a teenage male age from smoking with 14 years total of 3 persons (9.7), aged 15 years, amounting to 17 people (54.8), 16 years old numbering 6 people (19.4), and age 17 years numbering 5 people (16.1).

Table 3: The distribution of respondents based on the age of smoking.

\begin{tabular}{|c|c|c|}
\hline First-time Smoking & N & $\%$ \\
\hline $10-15$ year & 25 & 80.6 \\
\hline $16-17$ year & 6 & 19.3 \\
\hline Total & 31 & 100 \\
\hline
\end{tabular}

\section{Length of smoking}

Table 4: Distribution of respondents by old smoking that was experienced.

\begin{tabular}{|c|c|c|}
\hline Length of Smoking & $\mathbf{N}$ & $\%$ \\
\hline 1-5 years & 31 & 100 \\
\hline 6-10 years & 0 & 0 \\
\hline >10 years & 0 & 0 \\
\hline Total & 31 & 100 \\
\hline
\end{tabular}

The Data in Table 4 shows that the length of smoking experienced by the young men at Muhammadiyah Jayapura High School for 1-5 years amounted to 31 people (100).

\section{Average per day}

Data on Table 5 shows that the average of cigarettes that are in the consumption of young men in SMA Muhammadiyah Jayapura 1-10 stem amounted to 27 people (87.1), 11-20 rods amounting to 3 people (9.7), 21-30 rods amounting to 1 person (3.2).

Table 5: The distribution of respondents based on average cigarettes that are consumption.

\begin{tabular}{|c|c|c|}
\hline Average Per Day & N & $\%$ \\
\hline $1-10$ stem & 27 & 87.1 \\
\hline $11-20$ stem & 3 & 9.7 \\
\hline $21-30$ stem & 1 & 3.2 \\
\hline Total & 31 & 100 \\
\hline
\end{tabular}

\section{Smoking Place}

Table 6: The distribution of respondents based on the smoking place.

\begin{tabular}{|c|c|c|}
\hline Place of Smoke & N & \% \\
\hline House & 14 & 48.4 \\
\hline School & 0 & 0 \\
\hline General place & 17 & 51.6 \\
\hline Total & 31 & 100 \\
\hline
\end{tabular}

The Data in Table 6 showed that the smoking place was done by the young men in Muhammadiyah Jayapura High School at home as much as 15 (48.4), in public places around 16 (51.6).

\section{Smoking behavior}

Table 7: The distribution of respondents based on the smoking behavior.

\begin{tabular}{|c|c|c|}
\hline Smoking Behavior & N & \% \\
\hline Very often & 21 & 54,8 \\
\hline Often & 1 & 3,2 \\
\hline Sometimes & 9 & 41,9 \\
\hline Total & 31 & 100 \\
\hline
\end{tabular}

The Data in Table 7 shows that the smoking behavior that the young men at Muhammadiyah Jayapura High School is very often as much as 17 (54.8), often as much as 1 (3.2), and sometimes at least 13 (41.9).

\section{Anxiety}

Table 8: Respondent's distribution based on anxiety levels experienced.

\begin{tabular}{|c|c|c|}
\hline Stress & N & \% \\
\hline No anxiety & 1 & 3,2 \\
\hline Mild anxiety & 2 & 6,5 \\
\hline Moderate anxiety & 27 & 87,1 \\
\hline Severe anxiety & 1 & 3,2 \\
\hline Total & 31 & 100 \\
\hline
\end{tabular}

The Data in Table 8 showed that the level of anxiety that was experienced by male adolescents at Muhammadiyah Jayapura High School did not worry as much as 1 student (3.2), mild anxiety of 2 people (6.5), moderate anxiety 27 (87.1), severe anxiety as much as 1 person (3.2). 


\section{Bivariate analysis}

Table 9: Distribution of respondents to the level of anxiety relationship with smoking male adolescent behavior.

\begin{tabular}{|c|c|c|c|c|}
\hline & \multicolumn{3}{|c|}{ Behavior } & Total \\
\hline Anxiety & Very Often & Often & 1 & 3 \\
\hline No anxiety & 1 & 1 & 1 & 2 \\
\hline Mild anxiety & 1 & 0 & 7 & 25 \\
\hline Moderate anxiety & 18 & 0 & 0 & 1 \\
\hline Severe anxiety & 1 & 1 & 9 & 31 \\
\hline Total & 21 & 0 & & 2 \\
\hline
\end{tabular}

From the data Table 9 shows from 21 students who are not anxious and behave very often there are 3 students, from 2 students who are anxious to be mild and behave very often there is 1 person, from 1 student who are anxious and behave often smoking there is 1 person, and from 1 person who is anxious and behaving smoking sometimes there is 1 person. Moderate anxiety was 25 students with very often 18 and sometimes 7 students. From the table above, it shows that $\mathrm{P}$ value $=0.01(\mathrm{P}<0.05)$, so it can be concluded that there is strong correlation between the level of anxiety with smoking behavior of teenager at Muhammadiyah Jayapura High School.

\section{Discussion}

The $\mathrm{P}$ Value $=0,01(\mathrm{P}<0.05)$ meaning that there is strong connection between anxiety with smoking behavior of teenager in Muhammadiyah Jayapura High School. These results are different with the researched by Indri Kemala Nasution, S. PSI (2014) "Relationship between student anxiety level in working out the thesis on smoking behavior of male student PSIK UMY", from the analysis found that $\mathrm{P}$ value $=0.319$, so it can be concluded that there is no relationship between the anxiety level in working out the thesis on Smoking behavior. His research shows that smoking behavior in teenagers occurs mostly because smoking is used to produce flavor for fun, relaxation, enjoyment of taste, and satisfaction alone $[17,18]$.

Kurt Lewin (in Komalasari and Helmi, 2013) "Teen smoking behavior Junior High School", the study used a qualitative method with a phenyomological approach, while the data analysis was conducted with thematic and secretive analysts. Smoking behavior is a function of the environment and individual. That is, smoking behavior in addition to the factors from within the self is also caused by environmental factors. Individual factors can be psychosocial crises that occur within the individual. The environmental factors that can affect smoking behavior are family environments that include family structures, history, parent-child relationship patterns, foster patterns, and parental, peer-to-peer behavior, and exposure to advertising Smoking rooms [19]. Another study conducted by Kartika (2013) stating that there is no significant positive relationship between levels of anxiety with the frequency of smoking students of engineering Faculty of Muhammadiyah University of Malang. According to Komalasari Dan Helmi (2014) who conducted research on the factors that caused the behavior of smoking in adolescents one of them is a permissive attitude of parents with child behavior and peer solicitation is the dominant factor affects Smoking behavior in children.

The results of previous research that results are the same as the research results of current researchers, likely caused by some things. First, when the teenage men of SMA Muhammadiyah Jayapura experienced the adolescent anxiety had a strategy. Weiten and Lloyd (Farid Mashudi, 2012:221) suggest that coping with is an effort to manage, overcome, and mitigate the anxiety threat experienced so that adolescent strategy to confront anxiety is The high category (58.6\%) such as making an action plan and trying always positive thinking. Based on the results of the research of researchers, it is evident that from most of Muhammadiyah Jayapura high School teenagers if stress will put it to a sport, serves in the cafeteria, worship in the Musholah, or do something in accordance with His hobby [20].

Secondly, the male teenager who was the respondent in this study was a teenage man with a high school background. A person in education who has gained and knows the material about cigarettes is like what, the danger of smoking for health, then that person will refrain from smoking behavior. Teenagers who already have knowledge of smoking epidemiology, including the dangers of smoking for health, so that people are so not to divert anxiety with an adverse behavior, such as smoking. Thirdly, high school Muhammadiyah Jayapura is implementing a non-smoking area and giving sanctions on students with smoking. This can make a person not smoking. Smoking and knowledge of the regulatory area without smoking affects the level of compliance not to smoke [21,22].

\section{Summary}

Based on the discussion that has been explained in the previous chapter, it is known that from the research results of the relationship between the level of anxiety and smoking behavior in young men in Muhammadiyah Jayapura High School can be concluded that:

1. That the smoking behavior that the young men do in $\mathrm{Mu}-$ hammadiyah Jayapura High School is very often (54.8\%), often as much as (3.2), and sometimes as much as (41.9). 
2. The level of anxiety that was experienced by the young men at Muhammadiyah Jayapura High School did not worry as much as 1 student (3.2), Mild anxiety 2 people (6.5), moderate anxiety 27 (87.1), severe anxiety as much as 1 person (3.2).

3. $\mathrm{P}$ Value $=0,01(\mathrm{P}<0.05)$ meaning that there is strong connection between the level of anxiety with smoking behavior in young men in Muhammadiyah Jayapura High School.

\section{Suggestion}

1) It is hoped that a teenager who is active to further increase his knowledge and insight into the impact of smoking by following counseling-health counseling and accessing information in print or electronic media about the dangers of Smoking.

2) It is hoped that the teenagers smoke to cultivate a high will to quit smoking, to get together with friends who are smokers, and to do useful activities for themselves and others such as exercising with friends, making crafts, reading books, etc.

3) Schools are sought to be able to run counseling programs more optimally.

4) For relevant institutions to provide comprehensive and useful information about stress management and the impact of smoking to students in schools such as counseling programs.

5) For further researchers, this research can be used as a reference and should be with different research methods.

\section{Acknowledgement}

We would like to send my honor to Ministry of Health of Republic of Indonesia and the leader of Human Resource and Development Ministry of Health Republic of Indonesia.

\section{Declaration of Conflicting Interests}

The authors declared no potential conflict of interest with respect to the research, authorship, and/or publication of this article.

\section{References}

1. Soekkidjo Notoatmodjo (2009) Human resources development: PT Rineka Cipta: Jakarta.
2. Ali M, M Ansori (2008) Psychology Youth Development Learners. PT Bumi Aksara: Jakarta.

3. Moekijat (1999) Personel and human resources management: CV Mandar Maju: bandung.

4. Arikunto, Suharsimi (2000) Research Management: Cetakan kelima, Rineka Cipta: Jakarta.

5. Santrok (2002) Personality psychology, Malang UMM Press, Indonesia.

6. Sarwono, Sarlito (2002) Psycology of Teenager: PT. Raja Grafindo Persada: Jakarta.

7. Komalasari D, Helmi A (2002) The factors of causes of smoking behavior in adolescents. Journal of Psychology, Gadjah Mada University. Yogyakarta: Gadjah Mada University, Indonesia.

8. Soekidjo Notoatmodjo (2005) Health Research Methodology: PT Rineka Cipta: Jakarta.

9. Ali dan Asrori (2006) Psychology Youth Development Learners. PT Bumi Aksara: Jakarta

10. Weltan schauung (2007) Psychology Youth Development Learners. PT Garailmu: Yogyakarta.

11. Papilia Old, and Feldman (2008) Education Psychology, Bandung, PT Youth Rosdakarya.

12. Widyastuti (2009) Psychology teen: PT Raja Grafindo Persada: Jakarta.

13. Soekidjo Notoatmodjo (2010) Health Behavioral Sciences. Jakarta: PT. Rineka Cipta: Jakarta.

14. Thalib (2010) Statistics for medicine and health, Jakarta: Salemba Medika.

15. Riskesdas (2010) Agency for Health Research and development of the Republic of Indonesia Ministry of Health, National Report, Jakarta.

16. Notoatmodjo (2010) Health Research Methodology. Rineka Cipta, Jakarta.

17. Ministry of Health Republic of Indonesia (2011) Health Profile of Indonesia, Jakarta.

18. Jahja (2010) Family nursing, research, theoretical, and practical teaching books, Jakarta.

19. Muangman, Sarwono (2010) Psychology ( $9^{\text {th }}$ Edn.), Jakarta.

20. Azkiyati, Ade Maya (2012) The behavior of smoking with the self-esteem of adolescent men smoking in SMK Putra Bangsa Thesis. Faculty of Nursing Nursing Study Program, Depok, Indonesia.

21. Evi Irmayanti (2014) Influence of smoking behavior on academic achievement students D-III nursing Stikes Bakti Tunas Husada Tasikmalaya.

22. Rina Yuliarti (2014) Relationship between Smoking Behavior and Learning Achievement in Nursing Science Study Program Students of Riau University. Journal of Health Services Bakti Tunas Husada. 